\title{
Cell death during natural and induced luteal regression in mares
}

\author{
M. O. Al-zi'abi ${ }^{1}$, H. M. Fraser ${ }^{2}$ and E. D. Watson ${ }^{1 *}$ \\ ${ }^{1}$ Department of Veterinary Clinical Studies, University of Edinburgh, Easter Bush, Midlothian \\ EH25 9RG, UK; and ${ }^{2}$ MRC Human Reproductive Sciences Unit, 37 Chalmers Street, \\ Edinburgh EH3 9ET, UK
}

In mares, little information is available on the type of cell death that occurs during natural and induced luteal regression. Corpora lutea were collected from mares in the early luteal phase, days 3-4 $(n=4)$; mid-luteal phase, day $10(n=5)$; early regression, day $14(n=4)$; late regression, day $17(n=4)$; and 12 and $36 \mathrm{~h}(n=3$ per group) after $\mathrm{PGF}_{2 \alpha}$ administration on day 10 . Histological and ultrastructural sections were examined and TUNEL was used to detect DNA fragmentation. In early luteal regression, there were more pyknotic luteal cells and extracellular round dense bodies compared with the midluteal phase. By late regression, there was a significant decline $(P<0.01)$ in the number of round dense body clusters and a marked accumulation of lipid. Twelve and $36 \mathrm{~h}$ after $\mathrm{PGF}_{2 \alpha}$ administration, changes were similar to those seen in natural regression, but there was also a marked infiltration of neutrophils. Accumulation of lipid was not apparent until $36 \mathrm{~h}$ after $\mathrm{PGF}_{2 \alpha}$ administration. Ultrastructural examination revealed rarefaction and distortion of the mitochondrial cristae in most of the luteal cells by the mid-luteal phase. Luteal cells showed shrinkage, accumulation of lipid with foamy appearance, and disruption in both smooth endoplasmic reticulum and mitochondria during natural and induced regression. Some luteal cells showed fragmented or pyknotic chromatin characteristic of apoptosis. Other luteal cells showed crenation of the nuclear membrane and shrinkage of the nucleus, features not characteristic of apoptotic cell death. In late regression, capillaries were obstructed by swollen endothelial cells and round dense bodies. These results show that structural regression may be initiated as early as the mid-luteal phase, and is clearly visible by day 14 in natural regression and $12 \mathrm{~h}$ after induced regression. Apoptosis did appear to be involved in luteolysis in the equine corpus luteum, but non-apoptotic changes were also observed in some luteal cells during regression. Accumulation of lipid was a late feature of luteal regression.

\section{Introduction}

The equine corpus luteum is functional for about 14-15 days during the non-fertile cycle (Daels and Hughes, 1993). Luteal regression, characterized by a decrease in progesterone production (functional regression) and cellular demise of luteal tissue (structural regression), is thought to be brought about by secretion of uterine $\mathrm{PGF}_{2 \alpha}$ (Douglas and Ginther, 1975). However, the precise cellular mechanisms involved in luteolysis are not fully understood.

In general, cells die by three recognized mechanisms: apoptosis, necrosis (Kerr et al., 1972) or terminal differentiation (Stenn, 1983). During necrosis, cells develop increased permeability, which leads to cellular swelling, non-selective DNA degradation and inflammation in the surrounding tissues. Apoptosis is a process whereby cells die in a controlled manner. Morphologically, apoptosis is characterized by shrinkage and condensation of chromatin

*Correspondence

Email: elaine.watson@ed.ac.uk (marginated chromatin) or fragmentation into multiple, small dense bodies. Cells may then break up into discrete membrane-bound structures containing variable amounts of condensed chromatin or cytoplasm, which are then ingested by macrophages or neighbouring cells, or are extruded into the lumen of the blood vessels (Kerr et al., 1972; Wyllie et al., 1980). Alternatively, cells may shrink into a single dense round mass with a densely basophilic pyknotic nucleus (Wyllie et al., 1980). Terminal differentiation is another type of cell death, whereby certain types of cell, such as the outer squamous layers of skin and the granulosa cells next to the antrum of atretic ovarian follicles, undergo nuclear destruction or expulsion before the cessation of cellular function leads to cell death (Stenn, 1983; van Wezel et al., 1999).

Most recent studies on luteal cell death have used 3' endlabelling of the DNA fragments (TUNEL) to determine the type of cell death (Zheng et al., 1994; Bacci et al., 1996; Young et al., 1997; McCormack et al., 1998). In situations in which apoptosis is the major form of cell death in a tissue, this technique can assist in quantifying the degree of apoptosis (Negoescu et al., 1998). However, when necrosis 
occurs alongside apoptosis, TUNEL may lack specificity. Therefore, the use of this technique alone to detect the exact type of cell death in the corpus luteum may be misleading (Fraser et al., 1999). Definitive identification relies upon examination of the ultrastructure of cells (Wyllie et al., 1980).

Apoptosis has been described in luteal regression using electrophoresis or TUNEL to detect DNA fragments in cattle (Juengel et al., 1993; Zheng et al., 1994), sheep (Kenny et al., 1994), pigs (Bacci et al., 1996), women (Shikone et al., 1996; Yuan et al., 1997), monkeys (Young et al., 1997), golden hamsters (McCormack et al., 1998) and rabbits (Dharmarajan et al., 1994). However, another form of cell death was observed alongside apoptosis in the corpus luteum of women and monkeys (Fraser et al., 1995; Shikone et al., 1996).

In mares, the corpus luteum starts regressing functionally from day 10 to 12 onwards and, on day 16, the luteal cells decrease in size. By day 20, two types of cell degeneration were reported by histological examination: (i) pyknosis associated with shrunken nuclei and very condensed cytoplasm; and (ii) karyolysis characterized by lysis of chromatin (Van Niekerk et al., 1975). In another study, ultrastructural examination revealed that pyknotic nuclei were present on day 15 (Levine et al., 1979). Data from these studies were limited to cellular changes during natural luteolysis. There have been no reports on the types of cell death that take place during $\mathrm{PGF}_{2 \alpha}$-induced luteolysis in mares. While noting that forms of cell death other than apoptosis may occur during luteolysis (Shikone et al., 1996; Fraser et al., 1999), it is important to use techniques that can differentiate types of cell death to study changes that may be specific to mares. In the present study, biochemical and ultrastructural methods were used to investigate the point at which structural luteolysis occurs and the types of cell death involved in both natural and $\mathrm{PGF}_{2 \alpha}$-induced luteal regression.

\section{Materials and Methods}

\section{Animals}

Pony mares of mixed breeding, between 4 and 12 years of age and $250-450 \mathrm{~kg}$ body weight were used. The ovaries were examined each day during oestrus by transrectal ultrasonography to determine day of ovulation (day 0). Blood samples $(10 \mathrm{ml})$ were collected by jugular venepuncture into evacuated heparinized tubes for 5 days before ovariectomy to establish progesterone concentrations. Samples were centrifuged at $2000 \mathrm{~g}$ for $15 \mathrm{~min}$ at $4^{\circ} \mathrm{C}$, and the plasma was stored at $-20^{\circ} \mathrm{C}$ before assay. The ovary containing the corpus luteum was removed via a colpotomy incision after appropriate sedation and analgesia (Lawler et al., 1999).

\section{Tissue and blood collection}

Corpora lutea were obtained in early luteal phase, days 3-4 $(n=4)$; mid-luteal phase, day $10 \quad(n=5)$; early regression phase, day $14(n=4)$; late regression phase, day $17(n=4)$; and 12 and $36 \mathrm{~h}$ ( $n=3$ each) after intramuscular administration of the $\mathrm{PGF}_{2 \alpha}$ analogue, cloprostenol (Estrumate, $263 \mu \mathrm{g}$ per $500 \mathrm{~kg}$, Schering-Plough Animal Health Ltd, Uxbridge) on day 10 of the oestrous cycle. The ovaries were transferred on ice to the laboratory immediately after surgical removal. The ovarian cortex layer was removed, and the corpus luteum enucleated from the ovary and dissected free of connective tissue. The corpus luteum was weighed and then cut to give representative pieces of both the central and peripheral areas. The samples were fixed in freshly prepared $4 \%(\mathrm{w} / \mathrm{v})$ paraformaldehyde in 0.1 mol PBS $~^{-1}$ for $24 \mathrm{~h}$ at $4^{\circ} \mathrm{C}$, then processed the following day and embedded in paraffin wax. Samples (1 $\mathrm{mm} \times 1 \mathrm{~mm}$ ) from both peripheral and central areas of the corpora lutea were fixed for $4 \mathrm{~h}$ in $3 \%(\mathrm{v} / \mathrm{v})$ glutaraldehyde in 0.1 mol cacodylate $\mathrm{I}^{-1}$ buffer at $4^{\circ} \mathrm{C}$ and post-fixed with $2 \%(\mathrm{v} / \mathrm{v})$ osmium tetroxide for $1 \mathrm{~h}$ at room temperature. The samples were then washed three times in 0.1 mol cacodylate buffer $\mathrm{I}^{-1}$ and embedded in resin for transmission electron microscopy (TEM). Remaining representative samples were frozen in an isopentane-dry ice slurry and stored at $-70^{\circ} \mathrm{C}$.

\section{Histological examination}

Paraffin wax sections were stained by conventional histological methods using haematoxylin and eosin. Morphological criteria were used (Kerr et al., 1972; Wyllie et al., 1980) to differentiate and quantify cells that were actively undergoing apoptosis at the time of fixation, from dense small round bodies that were considered to represent residual products of apoptosis (apoptotic bodies). Apoptotic cells were defined as cells with nuclei containing condensed chromatin that was: (i) marginated into delineated, densely staining masses aligned with the nuclear membrane (marginated chromatin); (ii) shrunken into a single, round regularly shaped, dense, homogeneously staining mass (pyknotic appearance); or (iii) fragmented into multiple homogeneously dense masses (multiple fragments) situated inside the cells. Apoptotic bodies were considered to be remnants of apoptotic cell death, and defined as discrete membrane-bound structures containing various amounts of condensed chromatin and situated singly or in clusters between apparently viable cells, in the capillaries or extracellular space.

\section{Electron microscopy}

Ultra-thin sections of 40-70 nm thickness were obtained, stained with uranyl acetate and counterstained with lead citrate and examined with a Philips CM12 transmission electron microscope.

Detection of apoptosis by labelling 3' ends of the DNA fragments with digoxigenin-11-UTP (TUNEL)

TUNEL was performed on paraformaldehyde-fixed paraffin wax-embedded tissue using the technique described by Negoescu et al. (1998) with modifications. 
Sections $(4 \mu \mathrm{m})$ were mounted on slides coated with BioBond (British Biocell Int, Cardiff), deparaffinized and rehydrated. Endogenous peroxide activity was blocked by immersion in $3 \%(\mathrm{v} / \mathrm{v}) \mathrm{H}_{2} \mathrm{O}_{2}$ in methanol for 30 min. After two washes of $5 \mathrm{~min}$ each in $0.01 \mathrm{~mol} \mathrm{PBS} \mathrm{l}^{-1}(\mathrm{pH} 7.4)$, slides were incubated with proteinase $\mathrm{K}$ (Sigma, Poole) (20 $\mathrm{g} \mathrm{m} \mathrm{m}^{-1}$ in $20 \mathrm{mmol}^{\text {Tris I I }}{ }^{-1}, 2 \mathrm{mmol} \mathrm{CaCl}_{2} \mathrm{I}^{-1}, \mathrm{pH}$ 7.8) for $25 \mathrm{~min}$. Sections were then washed with PBS containing $5 \mathrm{mmol} \mathrm{EDTA}^{-1}$ for $10 \mathrm{~min}$ at room temperature to stop the proteinase $\mathrm{K}$ reaction. After two 5 min washes with PBS, the slides were equilibrated with terminal deoxynucleotidyl

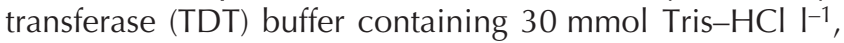
$\mathrm{pH} 7.2,140 \mathrm{mmol}^{2}$ sodium cacodylate $\mathrm{I}^{-1}$ and $1.5 \mathrm{mmol}$ $\mathrm{CoCl}_{2} \mathrm{I}^{-1}$, placed on an ice-cold plate and loaded with $2 \mathrm{nmol}$ digoxigenin-11-dUTP $\mathrm{I}^{-1}$ and $25 \mathrm{U} \mathrm{ml}^{-1}$ TDT in enzyme buffer. Negative control slides were treated with enzyme buffer lacking TDT. The slides were immediately covered with parafilm sheets and incubated at $37^{\circ} \mathrm{C}$ for 75 min. The parafilm was then removed and the slides washed twice ( 5 min each) in standard saline citrate buffer to stop the reaction. After a further 5 min wash with PBS, sections were incubated for $10 \mathrm{~min}$ at room temperature with $25 \%$ $(\mathrm{v} / \mathrm{v})$ normal rabbit serum in PBS, and then incubated for 90 min at room temperature in a humidified chamber with sheep anti-digoxigenin antibody (Boehringer, Mannheim) diluted 1:100 in blocking solution. After two further washes in PBS, the slides were incubated for $30 \mathrm{~min}$ at room temperature with biotinylated rabbit anti-sheep immunoglobulin (Vector Laboratories, Peterborough) diluted 1:500 in PBS. Two washes in PBS (5 min each) were followed by 30 min incubation at room temperature with horseradish peroxidase-avidin biotin complex (Dako, High Wycombe) diluted in PBS according to the manufacturer's instructions. After two further washes in PBS, sections were visualized with $0.05 \% \quad(\mathrm{w} / \mathrm{v}) \quad 3,3^{\prime}$-diaminobenzidine (Sigma) in 0.05 mol Tris- $\mathrm{HCl} \mathrm{I-1}, \mathrm{pH} 7.4$, and $0.01 \%(\mathrm{v} / \mathrm{v}) \mathrm{H}_{2} \mathrm{O}_{2}$. The sections were then washed in distilled water, lightly counterstained with haematoxylin, dehydrated in graded alcohol, cleared in xylene and mounted in DPX (distrene plasticiser xylene).

\section{Detection of lipid droplets using oil red $O$ stain}

Frozen sections $(8 \mu \mathrm{m})$ were stained with oil red $\mathrm{O}$ (Sigma) and then counterstained with haematoxylin (Filipe and Lake, 1990).

\section{Detection of neutrophils using periodic acid-Schiff reaction}

Formalin-fixed sections were stained with periodic acid-Schiff (PAS) reagent (Sigma) for $10 \mathrm{~min}$ and then counterstained with haematoxylin (Filipe and Lake, 1990).

\section{Quantification method}

The above stains were used on each tissue block, a minimum of three times. Two representative sections (peripheral and central) from each corpus luteum were selected and four fields per section were examined at $\times 400$ magnification. The identity of the sections was obscured to ensure blind counting. Individual clusters of dense bodies and pyknotic nuclei that showed positive immunostaining for TUNEL, or that were identified in haematoxylin and eosin stained sections, were counted separately. The results were expressed as mean \pm SEM. Sections were counted at $\times 400$ magnification to quantify the number of neutrophils. The total number of neutrophils for each stage of the oestrous cycle was expressed as mean \pm SEM. Quantimet image processing and analysis system 500 (Leica, Cambridge) was used to measure the proportion of the section stained by oil red $\mathrm{O}$ (area of the oil red $\mathrm{O}$ stain divided by the total area measured $\times 100$ ). Areas were analysed at $\times 200$ magnification. The system was optimized for each individual section on the basis of the density of the stain. The data were expressed as percentage mean \pm SEM per unit area. Two sections per corpus luteum and four per section were used in the quantification, as increasing the number of sections above two sections per corpus luteum and four fields per section did not alter the result. There was no difference between the mean of the variables in central and peripheral regions, and therefore data were combined to represent one variable.

\section{Progesterone assay}

Progesterone concentrations were determined in plasma by radioimmunoassay as described by Watson et al. (2000). The limit of detection of the assay was $0.5 \mathrm{ng} \mathrm{ml}^{-1}$ and the intra- and interassay coefficients of variation were 9.0 and $12.6 \%$, respectively.

\section{Statistical analysis}

The differences in early, mid-luteal, early and late regression corpora lutea were analysed by one-way analysis of variance using stage of the luteal phase as the betweensubject variable. Data from untreated mid-luteal phase corpora lutea were compared with corpora lutea after induced regression using a one-way analysis of variance with treatment as the between-subject variable. The data were then subjected to Tukey's test of multicomparison among means. Results were considered to be significantly different when $P<0.05$.

\section{Results}

\section{Corpus luteum mass and progesterone concentrations}

Morphological examination and progesterone concentrations for each corpus luteum were used to confirm the cycle stage. In three of the 23 corpora lutea, the designated stage of the cycle did not conform to the expected morphological appearance and progesterone concentration and these corpora lutea were therefore re-classified. In two corpora lutea that were collected on day 14 (early 


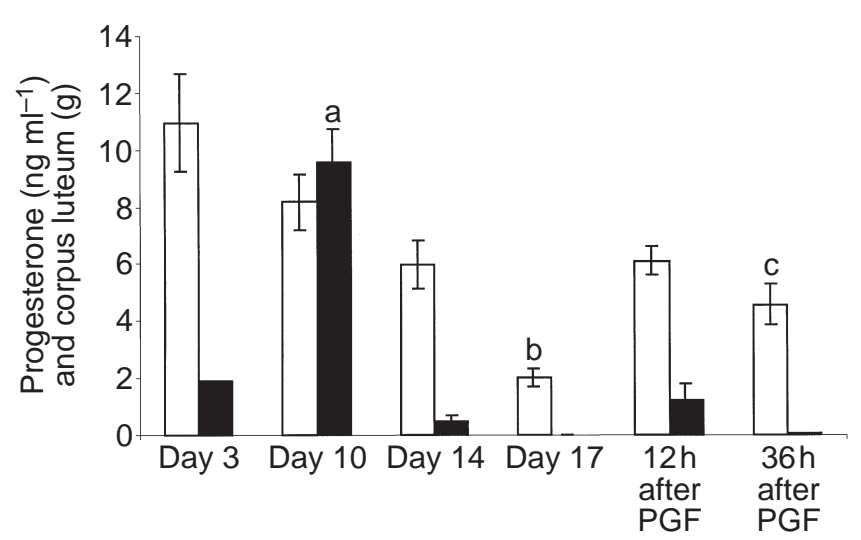

Fig. 1. Corpus luteum mass ( $\square$ ) and plasma progesterone concentrations $(\mathbf{\square})$ throughout the oestrous cycle and after $\mathrm{PGF}_{2 \alpha}$ administration $(263 \mu$ g cloprostenol per $500 \mathrm{~kg})$ in mares. Data are

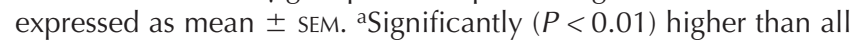
other groups; ${ }^{b}$ significantly $(P<0.05)$ lower than all other groups; and ${ }^{\mathrm{c}}$ significantly $(P<0.05)$ lower than during mid-luteal phase (day 10).

regression group), one of the animals had high progesterone concentrations $\left(9.4 \mathrm{ng} \mathrm{ml}^{-1}\right.$ ) together with luteal cells of healthy appearance. Therefore, this animal was reclassified to the day 10 (mid-luteal phase) group. Progesterone was undetectable in the other animal and there was histological evidence of marked structural degeneration consistent with the day 17 (late regression) group. Therefore, this animal was reclassified to the late regression phase. The third corpus luteum was collected on day 17 , but progesterone concentration was $1.2 \mathrm{ng} \mathrm{ml}^{-1}$ on the day of the surgery and its morphological changes coincided with those of the early luteal regression group (day 14). This animal was therefore reclassified to the early regression phase.

The mid-luteal phase was associated with maximum production of progesterone and concentrations were significantly higher $(P<0.01)$ than they were in other phases in the cycle. The time of luteolysis was day 14: progesterone concentrations on day 13 for the four corpora lutea collected in early regression were 2.1, 5.8, 2.4 and $1 \mathrm{ng} \mathrm{ml}^{-1}$, and by day 14 , progesterone concentrations had declined sharply to $0.5,1.2,0.5$ and $0.5 \mathrm{ng} \mathrm{ml}^{-1}$, respectively. All of the mares that were ovariectomized on day 17 had low concentrations of progesterone $\left(<0.5 \mathrm{ng} \mathrm{ml}^{-1}\right)$ for 2 days before ovariectomy. Twelve hours after $\mathrm{PGF}_{2 \alpha}$ administration on day 10, progesterone concentrations had declined significantly $(P<0.01)$ from $6.0 \pm 0.01 \mathrm{ng} \mathrm{ml}^{-1}$ before PGF $2 \alpha$ injection to $1.0 \pm 0.01 \mathrm{ng} \mathrm{ml}^{-1}$ by $12 \mathrm{~h}$ after the injection. By $36 \mathrm{~h}$, functional regression was complete and progesterone concentrations were $<0.5 \mathrm{ng} \mathrm{ml}^{-1}$ (Fig. 1).

The corpus luteum showed changes in mass, shape and colour throughout the oestrous cycle. During the early luteal phase, the corpora lutea were irregular in shape, blood-coloured and contained a large central blood clot. By day 10 , the corpus luteum became mushroom- or gourd- shaped, pink-to-purple, and four of the five corpora lutea still contained a clot of blood, although this was smaller than in the early corpus luteum. By day 14, two of four corpora lutea contained a small clot of blood, and the other two corpora lutea appeared to be homogeneous. By day 17 , the corpus luteum became round, cream or yellow, and comprised a solid mass of tissue. The mean mass of luteal tissue was significantly lower $(P<0.05)$ in the late luteal phase (day 17) and $36 \mathrm{~h}$ after $\mathrm{PGF}_{2 \alpha}$, than in the early and mid-luteal phase (Fig. 1).

\section{Luteal tissue histology and TUNEL immunostaining}

Sections were examined by both haematoxylin and eosin and TUNEL immunostaining, and quantitative analysis of apoptosis was carried out on both sets of sections. As the morphological appearance was similar with haematoxylin and eosin and TUNEL, only the TUNEL immunostaining results are shown (Fig. 2). The luteal cells in the mid-luteal phase were polyhedral to elongated, and had abundant cytoplasm containing spherical nuclei (Fig. 2a). Pyknotic cells with densely basophilic nuclei were rarely observed. Endothelial cells had oval-to-vesicular shaped nuclei in cross-section or elongated-to-spindle shaped nuclei in longitudinal section. By day 14, luteal cells exhibited nuclear degenerative changes (Fig. 2b). Pyknotic cells with densely basophilic nuclei were observed between apparently healthy luteal cells and were classified as apoptotic cells. Discrete membrane-bound structures containing various amounts of condensed chromatin were observed singly or in clusters between apparently viable cells, in capillaries and the extracellular space, and were classified as apoptotic bodies. In late regression (day 17), all the luteal cells had decreased in size and contained vacuoles with a foamy appearance (Fig. 2c). Fibroblasts and connective tissue infiltrated the corpora lutea; intercellular debris was evident, and leucocytes were common. The nuclear changes were similar to those observed in day 14 sections. Twelve hours after $\mathrm{PGF}_{2 \alpha}$ injection, a huge influx of neutrophils was seen, and a number of cells showed pyknotic nuclei and round dense bodies were present in the extracellular space. At $36 \mathrm{~h}$, most of the luteal cells were surrounded by neutrophils, and pyknotic cells and clusters of round dense bodies were abundant (Fig. 2d).

TUNEL immunostaining was found to be limited to pyknotic cells and round dense bodies. There was no immunoreactivity in interstitial cells, endothelial cells, apparently healthy luteal cells or other types of cell. Approximately $90 \%$ of pyknotic cells and dense bodies exhibited positive immunostaining with TUNEL. Positive pyknotic cells and dense bodies were seen during the midluteal phase (Fig. 2a), early regression (Fig. 2b), late regression (Fig. 2c), and $36 \mathrm{~h}$ after $\mathrm{PGF}_{2 \alpha}$ injection (Fig. 2d). Moreover, neutrophils also stained positively at $36 \mathrm{~h}$ after $\mathrm{PGF}_{2 \alpha}$ injection.

Quantitative analysis of haematoxylin and eosin and TUNEL-stained sections are shown (Fig. 3). Unstained 
pyknotic cells and round dense bodies in TUNEL-stained sections were not included in the quantitative analysis. In early regression, the number of pyknotic cells increased $(P<0.05)$ and remained without significant change until late regression. During induced regression, there was an increase in the number of pyknotic cells in the corpora lutea collected $36 \mathrm{~h}$ after $\mathrm{PGF}_{2 \alpha}(P<0.05)$ compared with those collected after $12 \mathrm{~h}$. Clusters of round dense bodies increased in early regression $(P<0.01)$, and declined in late regression $(P<0.01)$. After induced regression there was an increase in clusters of round dense bodies $36 \mathrm{~h}$ after $\mathrm{PGF}_{2 \alpha}$ $(P<0.01)$ compared with $12 \mathrm{~h}$ after $\mathrm{PGF}_{2 \alpha}$.

\section{Oil red $O$}

In the early luteal phase, most of the luteal cells showed intense staining for oil red O. By the mid-luteal phase, fewer luteal cells showed positive staining (Fig. 2e). In late regression (day 17), very intense staining was observed both intracellularly and extracellularly (Fig. 2f), reflecting high accumulation of lipid in the regressing corpus luteum. Twelve hours after $\mathrm{PGF}_{2 \alpha}$ administration, few cells showed oil red $\mathrm{O}$ staining and by $36 \mathrm{~h}$ there was moderate accumulation of lipid in most of the luteal cells. The percentage area of lipid (Fig. 4) in mid-luteal phase and early regression was decreased markedly $(P<0.01)$ compared with in the early luteal phase. By late regression, the percentage area of lipid had increased sharply $(P<0.001)$.

\section{Neutrophils}

PAS stains all types of polysaccharides. Neutrophils in the equine corpus luteum stained positively with PAS (Fig. $2 \mathrm{~g}$ ). In early and mid-luteal phases (Fig. $2 \mathrm{~h}$ ), as well as in early regression, occasional neutrophils were observed, particularly in the blood vessels. On day 17 , the number of neutrophils had increased slightly (Fig. 4). After PGF $_{2 \alpha}$ injection at both 12 and $36 \mathrm{~h}$, the number of neutrophils increased sharply $(P<0.001)$.

\section{Ultrastructural changes}

Ultrastructural examination during the early luteal phase (Fig. 5a) showed luteal cells with central or peripheral, ovalto-round shaped nuclei with one or more nucleoli. Heterochromatin was finely granular and uniformally dispersed in the nucleus. The cytoplasm contained vesicles or smooth endoplasmic reticulum (SER), electron dense bodies, ribosomes and lipid droplets. Mitochondria were round-to-elongated, and were normal in appearance with tubular and lamellar cristae. In the mid-luteal phase, luteal cells showed features similar to cells in the early luteal phase. However, the mitochondrial matrix was rarefied in some luteal cells. During regression, some luteal cells showed early stages of margination of chromatin (not shown), had fragmented chromatin (Fig. 5b), or appeared to be pyknotic (Fig. 5c). Single or clusters of dense round bodies (Fig. $5 \mathrm{~d}$ ) were observed in the extracellular space or in the capillaries (Fig. 5f). Other luteal cells showed nonapoptotic changes with shrinkage, crenation and involution of the nuclear membrane (Fig. 5e). The luteal cells showed accumulation of lipid, and disruption in both SER and mitochondria (Fig. 5b,c,e).

Endothelial cells were seen in the capillaries with ovalto-vesicular shaped nuclei, and contained aggregated dispersed heterochromatin with complex infoldings of the nuclear envelope during the mid-luteal phase (Fig. 6a). During regression, the endothelial cells appeared to protrude into the blood vessel lumens and were swollen or detached from the plasma membrane (Figs $5 \mathrm{~d}$ and $6 \mathrm{~b}$ ). Other cell types, such as macrophages, were abundant, engulfing apoptotic bodies or degenerated luteal cells (Fig. 6c). A marked influx of neutrophils was seen only during induced regression (Fig. 6d).

\section{Discussion}

This report has described cell death during natural and induced luteal regression in mares, combining, for the first time, morphological changes observed under light and electron microscopy with immunostaining for the $3^{\prime}$ end labelling of DNA (TUNEL technique). This is also the first description, to the author's knowledge, of cellular changes during $\mathrm{PGF}_{2 \alpha}$-induced luteolysis in mares. The detection of pyknotic luteal cells and round dense bodies that stained positively with TUNEL during natural and $\mathrm{PGF}_{2 \alpha}$-induced regression was strongly indicative of apoptosis. However, the crenation of the nuclear membrane and the shrinkage of the nuclei in the luteal cells were indicative of an additional form of cell death, possibly terminal differentiation.

In the present study, rarefied mitochondria indicative of minor degenerative changes were observed in some luteal cells in the mid-luteal phase (day 10), which is around the time of onset of declining progesterone concentrations in the oestrous cycle in mares (Van Niekerk et al., 1975). By day 14 , and by $12 \mathrm{~h}$ after $\mathrm{PGF}_{2 \alpha}$ administration on day 10 , marked structural degenerative changes were detected and circulating progesterone concentration had fallen to $<1 \mathrm{ng} \mathrm{ml}^{-1}$. Overall, these results indicate that marked structural changes did not precede the decrease in progesterone concentrations. These results are in agreement with studies in ruminants (Umo, 1975; Juengel et al., 1993; Zheng et al., 1994) and monkeys (Young et al., 1997).

The degeneration of the mitochondria in the mid-luteal phase in mares is an early step in the decline in progesterone concentrations, since the mitochondria are involved in steroidogenesis (Levine et al., 1979). Recent studies in other tissues indicate that disruption of mitochondria reflects early signs of apoptosis (Kroemer et al., 1998; Wilson, 1998). Since apoptotic cell death is regulated by oncoproteins in the mitochondria (Brenner et al., 1998), this period of regression may be the key time for further study of changes in the expression of the oncoproteins that initiate the cell death process. 

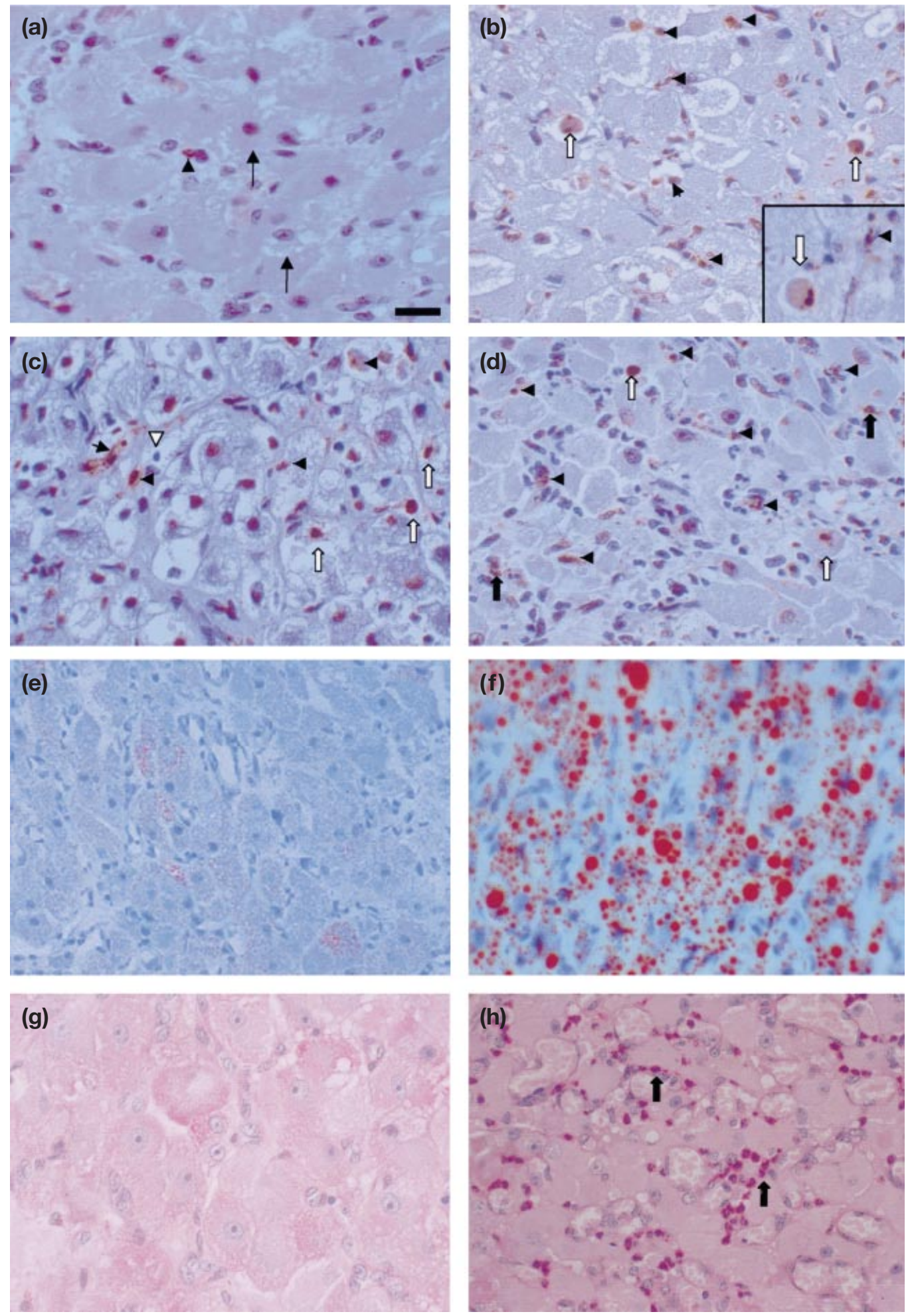

Fig. 2. TUNEL immunostaining in paraformaldehyde-fixed tissue; oil red $\mathrm{O}$ staining in frozen sections and periodic acid-Schiff (PAS) staining in formalin fixed tissue from the corpora lutea of mares. (a) Mid-luteal phase corpus luteum (day 10) showing luteal cells with healthy nuclei. One apoptotic round dense body is present. (b) Positive immunostaining of pyknotic cells and round dense bodies in the corpus luteum in early regression (day 14). Inset shows high magnification of apoptotic cell and round dense bodies. (c) Immunopositive staining in late regression corpus luteum (day 17) for both pyknotic cells and round dense bodies. (d) Corpus luteum $36 \mathrm{~h}$ after $\mathrm{PGF}_{2 \alpha}$ administration, neutrophils, pyknotic cells and round 
(a)

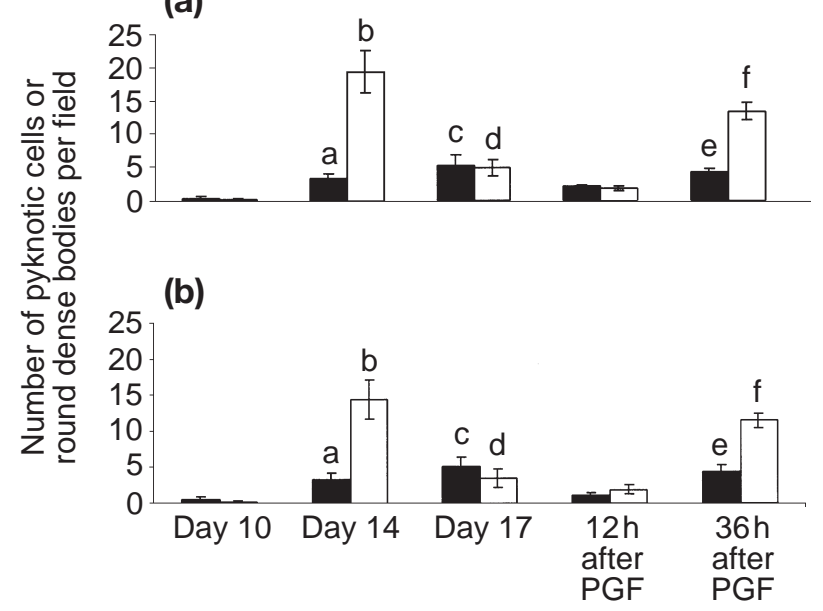

Fig. 3. Number of pyknotic cells ( $\square$ ) and round dense bodies ( $\square$ ) per field at $\times 400$ magnification expressed as mean \pm SEM in equine luteal tissue ( $n=3-4$ animals for each phase) during induced and natural regression. (a) TUNEL immunostaining; (b) paraformaldehyde-fixed tissue stained with haematoxylin and eosin. aSignificantly $(P<0.05)$ higher than during mid-luteal phase (day 10); bsignificantly $(P<0.01)$ higher than during late regression phase (day 17$)$; ${ }^{c d}$ significantly $(P<0.05)$ higher than during mid-luteal phase (day 10); ${ }^{\text {esignifi- }}$ cantly $(P<0.05)$ higher than during mid-luteal phase (day 10$)$ and $12 \mathrm{~h}$ after $\mathrm{PGF}_{2 \alpha}$ administration; ${ }^{\mathrm{f}}$ significantly $(P<0.01)$ higher than during mid-luteal phase (day 10) and $12 \mathrm{~h}$ after $\mathrm{PGF}_{2 \alpha}$ administration.

In the present study, both TUNEL technique and morphological examination under light and electron microscopy demonstrated the presence of pyknotic cells and round dense clusters of chromatin in the extracellular space, characteristic of apoptosis. The pathways of cell degeneration in natural and induced regression appeared to be broadly similar. It appears that luteal regression in mares may involve apoptosis in the elimination of degenerated and unwanted cells from the corpus luteum, in agreement with a previous ultrastructural study in sheep that showed apoptosis in luteal cells (Sawyer et al., 1991).

In the present study, TUNEL immunostaining was limited to pyknotic cells and round dense bodies. Paraffin waxembedded histological sections of marmoset corpus luteum have been shown to exhibit apoptosis both morphologically and immunohistochemically (by TUNEL) (Young et al., 1997). However, resin sections from the same tissue did not show the ultrastructural features associated with classic apoptosis, but rather autophagocytosis and nonlysosmal disintegration, and it may be that TUNEL over-represented apoptotic degeneration by staining non-apoptotic chromatin

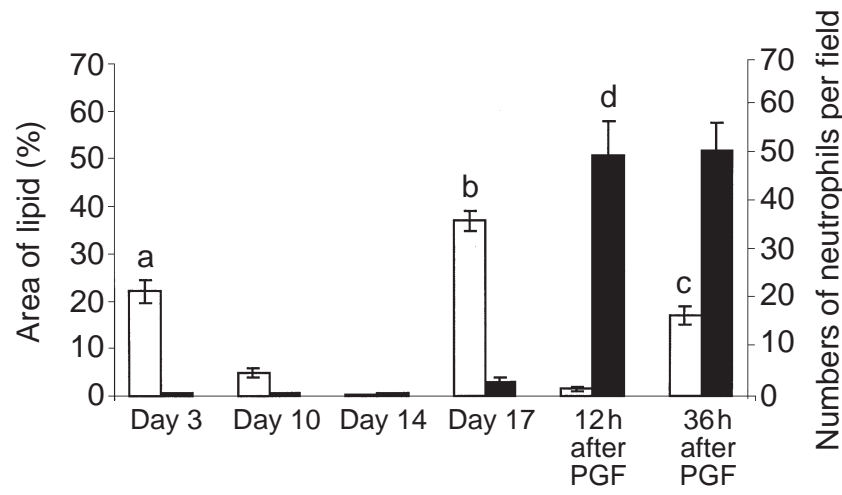

Fig. 4. The area fraction for oil red $\mathrm{O}$ stain $(\square)$ and number of neutrophils $(\square)$ in equine luteal tissue, expressed as mean \pm SEM, during natural and induced regression. aSignificantly $(P<0.01)$ higher than during mid-luteal phase (day 10); bsignificantly $(P<0.001)$ higher than during mid-luteal (day 10$)$ and early regression phases (day 14$)$; ${ }^{\mathrm{c}}$ significantly $(P<0.01)$ higher than during mid-luteal phase (day 10) and $12 \mathrm{~h}$ after $\mathrm{PGF}_{2 \alpha}$ administration; ${ }^{d}$ significantly $(P<0.001)$ higher than during mid-luteal phase (day 10).

(Fraser et al., 1999). Although many studies have used TUNEL to detect apoptosis, few have investigated the death of the luteal cells ultrastructurally. In the present study, results from haematoxylin and eosin staining and TUNEL were confirmed by electron microscopy, highlighting the importance of ultrastructural examination of tissues in investigating cell death during regression.

When haematoxylin and eosin and TUNEL staining were used to quantitate changes in the corpus luteum during regression, the peak increase in round dense bodies occurred in the early luteal phase (day 14), and was followed by the sharp decrease during late natural regression (day 17), indicating an active removal mechanism. It is not clear whether ultimately these round dense bodies undergo phagocytosis or are flushed out of the corpus luteum via the blood supply, but data from the present and previous studies indicate that elimination by macrophages is likely (Wyllie et al., 1980; Manjog and Joris, 1995). The increased numbers of macrophages during luteal regression, observed ultrastructurally in the present study and immunocytochemically in that of Lawler et al. (1999), indicate a role for macrophages in the removal of apoptotic bodies.

The crenation of the nuclear membrane with shrinkage of the nucleus seen in some luteal cells during luteal

dense bodies show positive immunostaining. (e) Oil red O staining in mid-luteal phase corpus luteum showing lipid droplets in a few luteal cells. (f) Accumulation of lipid droplets in late regression corpus luteum. (g) Mid-luteal phase corpus luteum stained with PAS showing healthy normal cells and no neutrophils. (h) Corpus luteum $12 \mathrm{~h}$ after $\mathrm{PGF}_{2 \alpha}$-induced luteolysis, showing a huge influx of neutrophils associated with vasodilation. Thin black arrows indicate healthy luteal cells, thick white and black arrows indicate pyknotic cells and neutrophils, respectively, black and white arrowheads indicate round dense bodies and unstained round dense bodies, respectively. Scale bar represents $20 \mu \mathrm{m}$ and $10 \mu \mathrm{m}$ (inset). 

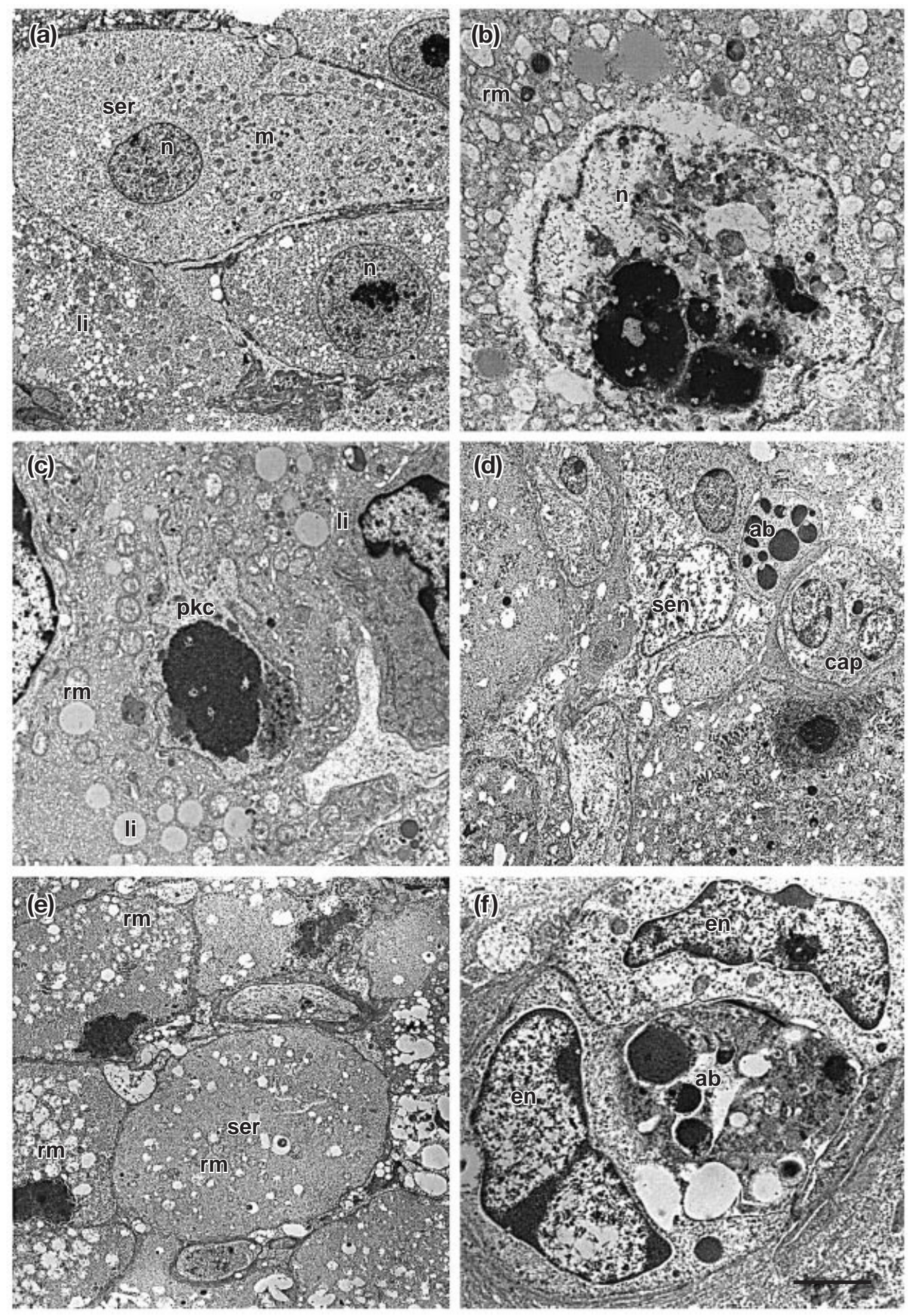

Fig. 5. Ultrastructural changes in the mare corpus luteum during natural regression. (a) Luteal cells in early luteal phase (day 3) showing typical structure of hormone producing cells, with spherical nuclei (n), healthy mitochondria (m) and smooth endoplasmic reticulum (ser) and lipid droplets (li). (b) Degenerated luteal cell in early regression phase showing nucleus (n) with fragmented masses of chromatin, shrinkage in the nuclear membrane and rarefied mitochondria (rm). (c) Luteal cell in late regression phase (day 17) showing chromatin with pyknotic appearance $(\mathrm{pkc})$, lipid droplets and rarefied mitochondria. (d) Early regression phase (day 14) corpus luteum showing cluster of round dense bodies, believed to be apoptotic bodies (ab) in the extracellular space, a capillary (cap) with two swollen endothelial cells, and another endothelial cell with swelling (sen). (e) Luteal cells in early regression showing crenation of the nuclear membrane and shrinkage of the nucleus, condensation of the smooth endoplasmic reticulum and rarefied mitochondria ( $\mathrm{rm}$ ). (f) Late regression (day 17) showing capillary with endothelial cells (en) obstructed by apoptotic bodies and debris. Scale bar represents (a) 3, (b) 0.1, (c) 1, (d) 1.5, (e) 2 and (f) $0.3 \mu \mathrm{m}$. 

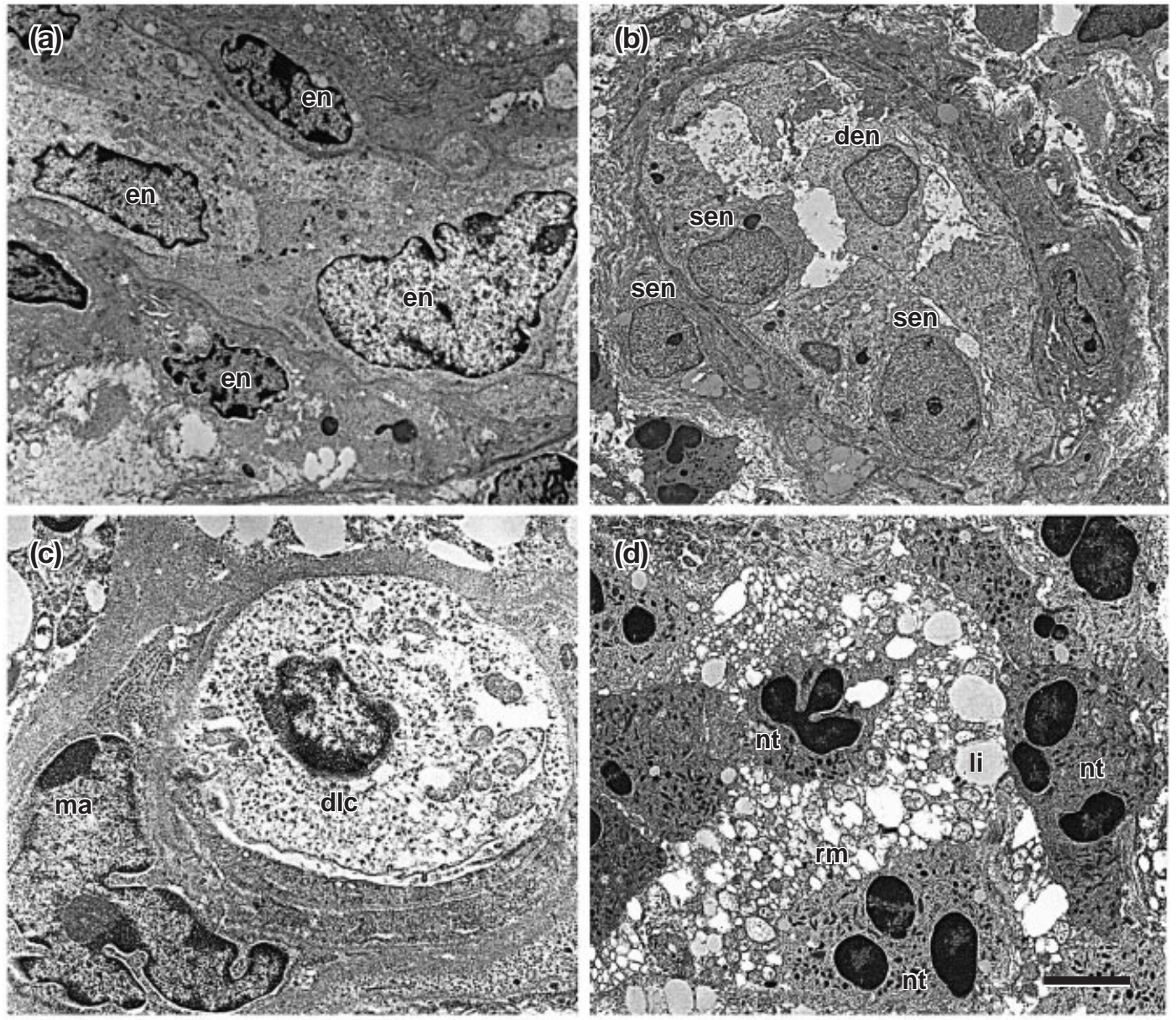

Fig. 6. Ultrastructural changes in the equine corpus luteum throughout late regression and after $\mathrm{PGF}_{2 \alpha^{-}}$ induced luteolysis. (a) Healthy endothelial cells (en) in mid-luteal phase showing elongated flattened shape with jagged membrane and a dense mass of chromatin in the nucleus. (b) Endothelial cells appeared to protrude into the blood vessel lumens swollen (sen) and detached from the plasma membrane (den) during induced regression. (c) Macrophage (ma) engulfing whole degenerated luteal cell (dlc) during late regression phase. (d) Massive influx of neutrophils (nt), lipid droplets (li) and rarified mitochondria (rm) $36 \mathrm{~h}$ after PGF $_{2 \alpha}$ administration. Scale bar represents (a,d) 2, (b) 3 and (c) $1 \mu \mathrm{m}$.

regression in mares may indicate the presence of an additional non-apoptotic form of cell death at luteolysis. It is possible that these cells were undergoing the type of cell death known as terminal differentiation in which progressive condensation of nuclear material results eventually in pyknosis and nuclear destruction or expulsion (van Wezel et al., 1999). In the regressing corpus luteum of marmosets, autophagocytosis and nonlysosmal disintegration may occur (Fraser et al., 1999). In autophagocytosis, the nucleus disintegrates and is digested by autolysosomes and, in nonlysosmal disintegration, organelles swell and formation of vacuoles and cytoplasmic destruction is followed by nucleus disintegration. However, these changes were not observed in the present study in mares.

TUNEL and ultrastructural examination confirmed that endothelial cells did not show any morphological signs of apoptosis, but that they did show signs of swelling and detachment from the walls of the blood vessels. Ultrastructural studies have shown that apoptosis occurs in endothelial cells during regression of the corpora lutea in guinea-pigs (Azmi and O'Shea, 1984) and in sheep after $\mathrm{PGF}_{2 \alpha}$-induced regression (Sawyer et al., 1990), but that it does not occur in cows (Augustin et al., 1995; Modlich et al., 1996). These studies strongly indicate that there are species differences in the fate of endothelial cells during luteolysis, and that the vasculature in bovine and equine corpora lutea regresses in a similar manner.

This is the first report, to the authors' knowledge, showing infiltration of neutrophils into the corpus luteum after $\mathrm{PGF}_{2 \alpha}$-induced luteolysis in domestic animals. An intense infiltration of neutrophils was observed 12 and $36 \mathrm{~h}$ after $\mathrm{PGF}_{2 \alpha}$ administration. Influx of neutrophils during 
luteal regression has been reported during spontaneous regression in hamsters, indicating that neutrophils assist in initiating luteal regression in this species (McCormack et al., 1998). Although the essential function of neutrophils is phagocytosis, they also initiate and modify the magnitude and duration of the acute inflammatory processes (Jain, 1993). It has been proposed by studies in the hamster corpus luteum that these cells play a role in luteal regression via cytokine secretion (McCormack et al., 1998).

A marked increase in lipid droplets during luteal regression was observed. This accumulation of lipid was seen in late regression (day 17), but not in early regression (day 14), indicating that accumulation of lipid is a feature of late regression, occurring after the onset of structural regression. This time course of events was confirmed by observations after $\mathrm{PGF}_{2 \alpha}$-induced luteolysis. At $12 \mathrm{~h}$ after $\mathrm{PGF}_{2 \alpha}$ administration, there was no lipid accumulation, despite the onset of structural regression, but by $36 \mathrm{~h}$ after $\mathrm{PGF}_{2 \alpha}$ administration, there was a marked lipid accumulation. Accumulation of lipid is associated with corpus luteum regression in sheep (Deane et al., 1966; Umo, 1975), cows (Priedkalns and Weber, 1968), sows (Waterman, 1980), rats (Guraya, 1975) and marmosets (Young et al., 1997). The exact mechanism by which lipid accumulation occurs during regression is not well understood. A degeneration in mitochondria and SER has been proposed to result in a decline in progesterone production and to play a role in the accumulation of lipid (Umo, 1975; Levine et al., 1979). However, the present study showed that accumulation of lipid does not occur directly in response to a decline in progesterone production and the luteolytic effect of $\mathrm{PGF}_{2 \alpha}$, but requires a period of time to develop.

In conclusion, degenerative changes in the equine corpus luteum may be initiated by day 10 (mitochondrial rarefaction), and apoptotic bodies and cells were present by day 14 of the cycle and $12 \mathrm{~h}$ after $\mathrm{PGF}_{2 \alpha}$ injection. Nonapoptotic changes were also observed in some luteal cells during regression. Lipid accumulation is a feature of late regression. A marked influx of neutrophils was observed after $\mathrm{PGF}_{2 \alpha}$-induced regression.

M. O. Al-zi'abi received a fellowship from Alba'ath University. The authors would like to thank S. Thomson for performing the progesterone assay, S. Mitchell for help in processing the tissue for electron microscopy, A. Hinojosa and B. Berrocal for assistance with ovarian scans, and H. Pedersen, H. Tremaine, K. Kyles and E. Clutton for their help with the ovariectomies. R. Else and D. Brownstein provided expert help in interpreting the electron micrographs.

\section{References}

Augustin HG, Braun K, Telemenakis I, Modlich U and Kuhn W (1995) Ovarian angiogenesis. Phenotypic characterization of endothelial cells in a physiological model of blood vessel growth and regression American Journal of Pathology 147 339-351

Azmi TI and O'Shea JD (1984) Mechanism of deletion of endothelial cells during regression of the corpus luteum Laboratory Investigation $\mathbf{5 1}$ 206-217
Bacci ML, Barazzoni AM, Forni M and Costerbosa GL (1996) In situ detection of apoptosis in regressing corpus luteum of pregnant sow: evidence of an early presence of DNA fragmentation Domestic Animal Endocrinology 13 361-372

Brenner C, Marzo I and Kroemer G (1998) A revolution in apoptosis: from a nucleocentric to a mitochondriocentric perspective Experimental Gerontology 33 543-553

Daels PF and Hughes JP (1993) The normal estrous cycle. In Equine Reproduction pp 121-132 Eds AO McKinnon and JL Voss. Lea and Febiger, Philadelphia

Deane HW, Hay MF, Moor RM, Rowson LE and Short RV (1966) The corpus luteum of the sheep: relationships between morphology and function during the oestrous cycle Acta Endocrinology 51 245-263

Dharmarajen AM, Goodaman SB, Tilly KI and Tilly JL (1994) Apoptosis during functional corpus luteum regression: evidence of a role for chorionic gonadotropin in promoting luteal cell survival Endocrine Journal 2 295-303

Douglas RH and Ginther OJ (1975) Effects of prostaglandin $F_{2 \alpha}$ on the oestrous cycle and pregnancy in mares Journal of Reproduction and Fertility Supplement 23 257-261

Filipe MI and Lake BD (1990) Appendix. In Histochemistry in Pathology 2nd Edn pp 449-455 Churchill Livingstone, Edinburgh

Fraser HM, Lunn SF, Cowen GM and Illingworth PJ (1995) Induced luteal regression in the primate: evidence for apoptosis and changes in c-myc protein Journal of Endocrinology 147 131-137

Fraser HM, Lunn SF, Harrison DJ and Kerr JB (1999) Luteal regression in the primate: different forms of cell death during natural and gonadotropinreleasing hormone antagonist or prostaglandin analogue-induced luteolysis Biology of Reproduction 61 1468-1479

Guraya SS (1975) Histochemical observations on the lipid changes in the rat corpus luteum during various reproductive states Journal of Reproduction and Fertility 42 59-65

Jain NC (1993) Neutrophils. In Essentials of Veterinary Hematology p. 222 Lea and Febiger, Philadelphia

Juengel JL, Garverick HA, Johnson AL, Youngquist RS and Smith MF (1993) Apoptosis during luteal regression in cattle Endocrinology 132 249-254

Kenny N, Williams RE and Kelm LB (1994) Spontaneous apoptosis of cells prepared from the nonregressing corpus luteum Biochemical Cell Biology 72 531-536

Kerr JF, Wyllie AH and Currie AR (1972) Apoptosis: a basic biological phenomenon with wide-ranging implications in tissue kinetics British Journal of Cancer 26 239-257

Kroemer G, Dallaporta B and Resche-Rigon M (1998) The mitochondrial death/life regulator in apoptosis and necrosis Annual Review of Physiology 60 619-642

Lawler DF, Hopkins J and Watson ED (1999) Immune cell populations in the equine corpus luteum throughout the oestrous cycle and early pregnancy: an immunohistochemical and flow cytometric study Journal of Reproduction and Fertility 117 281-290

Levine H, Wight T and Squires E (1979) Ultrastructure of the corpus luteum of the cycling mare Biology of Reproduction 20 492-504

McCormack JT, Friederichs MG, Limback SD and Greenwald GS (1998) Apoptosis during spontaneous luteolysis in the cyclic golden hamster: biochemical and morphological evidence Biology of Reproduction 58 255-260

Manjog D and Isabelle J (1995) Apoptosis, oncosis and necrosis. An overview of cell death American Journal of Patholology 146 3-15

Modlich U, Kaup FJ and Augustin HG (1996) Cyclic angiogenesis and blood vessel regression in the ovary: blood vessel regression during luteolysis involves endothelial cell detachment and vessel occlusion Laboratory Investigation 74 771-780

Negoescu A, Guillermet $\mathrm{CH}$, Lorimier PH, Robbet C, Lantuejoul S, Brambilla E and Labat-Moleur F (1998) TUNEL apoptotic cell detection in archived paraffin-embedded tissues Biochemica 3 36-41

Priedkalns J and Weber AF (1968) Ultrastructural studies of the bovine Graafian follicle and corpus luteum Zeitschritft fur Zellforschung und Mikroskopische Anatomie 91 554-573

Sawyer HR, Niswender KD, Braden TD and Niswender GD (1990) Nuclear 
changes in ovine luteal cells in response to PGF $_{2 \alpha}$ Domestic Animal Endocrinology $7229-237$

Shikone T, Yamoto M, Kokawa K, Yamashita K, Nishimori K and Nakano R (1996) Apoptosis of human corpora lutea during cyclic luteal regression and early pregnancy Journal of Clinical Endocrinology and Metabolism $812376-2380$

Stenn KS (1983) The skin. In Histology: Cell and Tissue Biology 5th Edn pp 569-606 Ed. L Weiss. Elsevier, New York

Umo I (1975) Effect of prostaglandin $F_{2 \alpha}$ on the ultrastructure and function of sheep corpora lutea Journal of Reproduction and Fertility 43 287-292

Van Niekerk CH, Morgenthal JC and Gerneke WH (1975) Relationship between the morphology of and progesterone production by the corpus luteum of the mare Journal of Reproduction and Fertility Supplement 23 171-175

van Wezel IL, Dharmarajan AM, Lavranos TC, Rodgers RJ (1999) Evidence for alternative pathways of granulosa cell death in healthy and slightly atretic bovine antral follicles Endocrinology 140 2602-2612

Waterman RA (1980) Lipid metabolism and in vitro production of progesterone and prostaglandin $\mathrm{F}$ during induced regression of porcine corpora lutea Prostaglandins 20 73-85

Watson ED, Pedersen HG, Thomson SR and Fraser HM (2000) Control of follicular development and luteal function in the mare: effects of a GnRH antagonist Theriogenology 54 599-609

Wilson MR (1998) Apoptosis: unmasking the executioner Cell Death Differentiation 5 646-652

Wyllie AH, Kerr JFR and Currie AR (1980) Cell death: the significance of apoptosis International Review of Cytolology 68 251-300

Young FM, Illingworth PJ, Lunn SF, Harrison DJ and Fraser HM (1997) Cell death during luteal regression in the marmoset monkey (Callithrix jacchus) Journal of Reproduction and Fertility 111 109-119

Yuan W and Giudice L C (1997) Programmed cell death in human ovary is a function of follicle and corpus luteum status Journal of Clinical Endocrinology and Metabolism 82 3148-3155

Zheng J, Fricke PM, Reynolds LP and Redmer DA (1994) Evaluation of growth, cell proliferation, and cell death in bovine corpora lutea throughout the estrous cycle Biology of Reproduction 51 623-632

Received 25 June 2001.

First decision 10 September 2001.

Accepted 10 October 2001. 